\title{
A szovjet flotta új háborúra történő felkészülésének tervei (1936-1956) L.resz
}

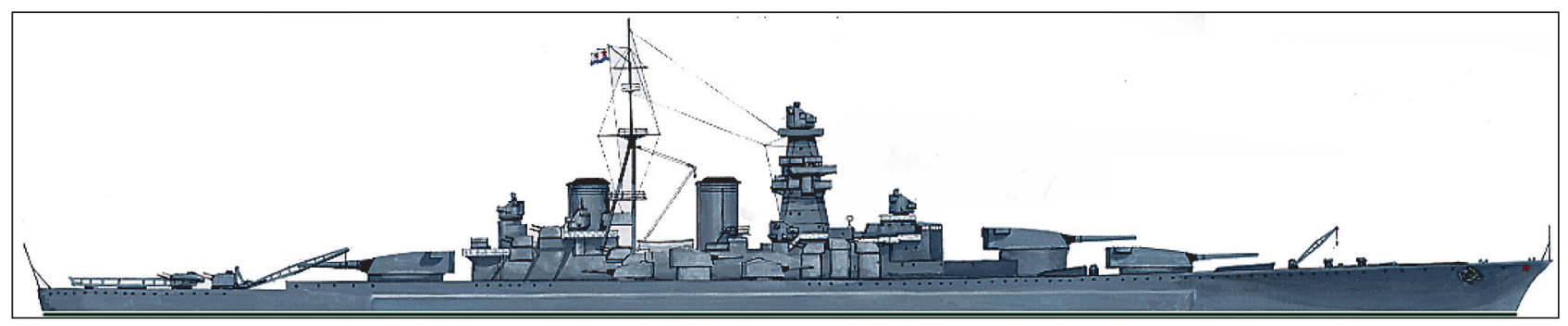

1. ábra. A SZOVJETSZKIJ SZOJUZ osztály grafikája

S ztálin két nagy flottaépítési programot vezényelt az általa elkerülhetetlennek tartott nagy európai háborúra való felkészülés jegyében. Az első 1936-1945-ös lefutású lett volna, a második az 1946-1955-ös időszakot fedte le. Az elsőt a spanyolországi polgárháború, illetve a német és japán erők gyors növekedése generálta. A másodikat egész Nyugat-Európa „felszabadítása” indokolta. Az első program 1941 januárjában azért szakadt meg, mert a Szovjetunió, a tervektől eltérően korábban és kedvezőtlen pozícióban lépett be a háborúba. A második programot Joszif Visszarionovics Szálin 1953. március 5-én bekövetkezett hirtelen halála álította le. Utódai nyomban leállították a költséges programokat, mert az amerikai nukleáris fölény miatt semmi reményük sem volt győzelmes összecsapásokra.

\section{AZ ELSŐ PROGRAM AZ ÓCEÁNI FLOTTA KIÉPÍTÉSÉRE}

Az 1936 után beindult munkálatok az alábbi főbb hajóegységeket irányozták elő:

- 59150 t-s csatahajó

- 32240 t-s csatacirkáló

- KIROV osztályú, 9550 t-s cirkáló

- CSAPAJEV osztályú, 12000 t-s cirkáló

- torpedóromboló

- partvédő

- tengeralattjáró

- segédhajó

- Összes hadiegység:

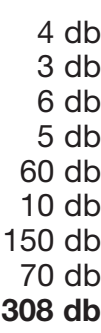

Röviden ki kell térni a szovjet nehéz hajóegységek kérdésére. 1938-ban kezdték meg a nagy egységek tervezését, de az olasz, amerikai tervek tervezett vásárlása 1939

ÖSSZEFOGLALÁS: Az első óceáni flotta kiépítésére irányuló sztálini flottaépítési program 1936-1945-ös lefutású lett volna, a második pedig az 19461955-ös időszakot fedte le. Az első program egyebek mellett négy darab hatvanezer tonnás csatahajó építését irányozta elö, ám ez a háború miatt nem valósult meg. A II. világháború utáni program a zsákmányanyag begyúijtésének időszaka volt, amikor számszerúen jelentősen nőtt a szovjet flotta. Végül a CSAPAJEV és a SZVERDLOV osztály cirkálóiból a szovjet hajógyárakban 1955-ig 18 darab készült el.

KULCSSZAVAK: szovjet haditengerészet, flottafejlesztés, csatahajó, cirkáló szeptemberében meghiúsult. Ekkor Németországhoz fordultak és olajért több jelentős tervet megszereztek. Ezek: a LÜTZOW befejezetlen nehézcirkáló (később TALLIN), a BISMARCK osztály teljes tervanyaga, megrendelve legyártásra $6 \mathrm{db}$ torony, 2-2 db $38 \mathrm{~cm}$-es löveggel, a H osztályú csatahajó 40,6 cm-es lövegtornyai és tűzvezető rendszere. A német fél eladta a terveket, mert biztos volt benne, hogy 4-5 év alatt realizálni nem tudják, közben pedig a háborús helyzet úgy is változik.

A szovjet fél magánúton, az amerikai Gibbson \& Cox irodától megrendelte egy 62000 t vízkiszorítású csatahajó terveit, 45,7 cm-es lövegekkel. Ennek irrealitása nyilvánvaló volt, az USA sem épített ekkora hadihajót, hogy a szovjet ipar hogy boldogult volna vele, ez soha nem derült ki. A rajzok jó részét mindenesetre 1940-ig megkapták.

\section{2. ábra. A KIROV cirkáló 1944-ben}

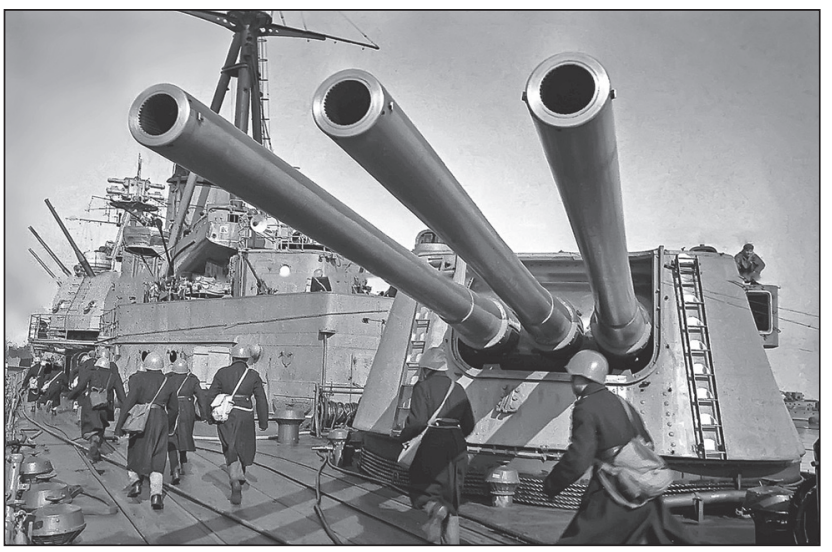

ABSTRACT: The first Stalin's fleet-building program aiming at establishing the ocean-going fleet was planned to be realized from 1936 to 1945 , the second one would have covered the period of time between 1946 and 1955 . According to the first program, building, inter alia, four battleships of 60,000 tons was scheduled, but it was not realized because of the war. The program after the World War II was the term of gathering the spoil of war, during which the Soviet fleet grew quantitatively to a considerable extent. By 1955, 18 Chapayev and Sverdlov class cruisers were built by the Soviet shipyards.

KEY WORDS: Soviet Navy, fleet development, battleship, cruiser 


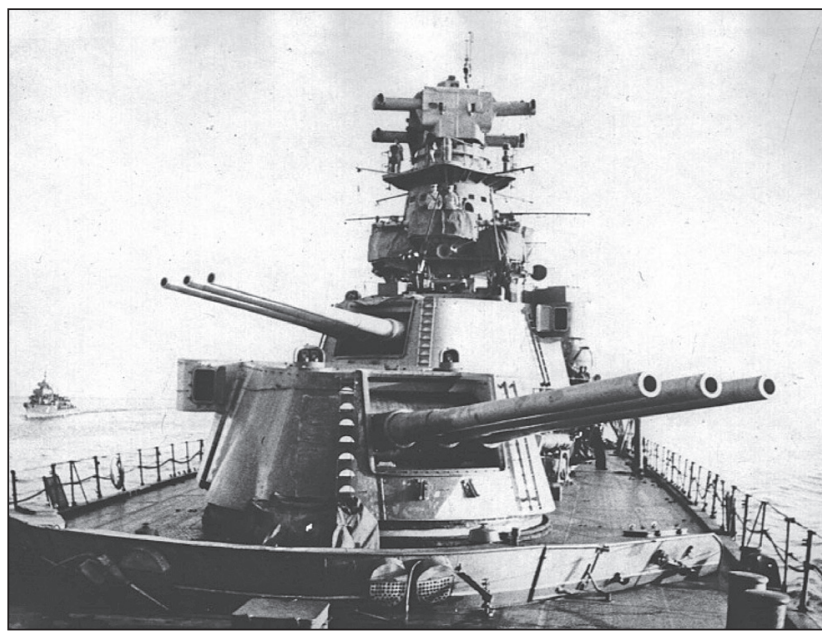

3. ábra. A KIROV-ot 180 mm-es B1P típusjelú ágyúkkal szerelték fel

Sztálin 1938-39-ben olasz terveket is rendelt VITTORIO VENETO néven, 9 db 40,6 cm-es löveggel. Ez nagyobb volt, mint amit Olaszország saját részére tudott gyártani. A rajzokat megkapták, kifizették.

Három nagy hajógyár kialakítását indították el. Új üzem épült északon, Szeverodvinszknél (ex Molotovszk) - ez nem készült el 1942-ig sem, csak 1950 után fejezték be. A Leningrádban és Nyikolajevben lévő meglévő hajógyárakat egy-egy nagy sólyával kibővítették. A munka beindult. A SZOVJETSZKIJ SZOJUZ osztály (59.150/65.150 t vízkiszorítás) névadóját 1938-ban kezdték építeni Leningrádban. A munka 1941 januárjában megszakadt, soha sem fejezték be, állítólag, felépítmények nélkül a test 19,4\%-a volt kész.

A második egység a SZOVJETSZKAJA UKRAJNA volt, amelyet a Nyikolajevben lévő Marti hajógyárban építettek 1939. július 17-től. A munka 1941 júniusában leállt, 1941 augusztusában német csapatok foglalták el a gyárat. A hajó pár fotója ebből a korszakból ismert, állítólag a test mindössze 7,5\%-a volt meg. 1944 tavaszán a visszavonuláskor pár robbantást végeztek rajta, de állva maradt a sólyán.
A harmadik egység a SZOVJETSZKAJA BELORUSZIJA lett volna, építését 1938-ban szeverovdvinszki gyárnak adták ki. Ez a munka 1939. december 21-én kezdődött.

Ugyanitt 1940. július 22-én megkezdett SZOVJETSZKAJA ROSSZIJA alig jutott túl a gerincfektetésen, és a munkálatok 1941 tavaszán leálltak. Egy-egy hajó 1180 millió rubelbe került volna, hatalmas összeg a korabeli viszonyokhoz képest. Az első egységnél 1948. május 29-én döntöttek a lebontásról, ezt 1950-ig elvégezték. A nyikolajevi hajót 1947 tavaszán bontották el, Molotovszkban az első hajót 1944-ig, a másodikat 1947-ben vágták szét.

\section{1. táblázat. A flottaépítés helyzete 1941 nyarán}

\begin{tabular}{|l|l|}
\hline \multicolumn{1}{|c|}{ Hadrendben van } & \multicolumn{1}{c|}{ Épülöben } \\
\hline $3 \mathrm{db}$ régi csatahajó & $4 \mathrm{db}$ új csatahajó \\
\hline $5 \mathrm{db}$ kis és nagy cirkáló & $2 \mathrm{db}$ csatacirkáló \\
\hline 8 flottillavezető & $4 \mathrm{db}$ cirkáló \\
\hline $64 \mathrm{db}$ romboló & $45 \mathrm{db}$ romboló \\
\hline $278 \mathrm{db}$ tengeralattjáró & $90 \mathrm{db}$ tengeralattjáró \\
\hline $\begin{array}{l}18 \mathrm{db} \text { régi I. világháborús } \\
\text { tengeralattjáró }\end{array}$ & \\
\hline $\mathbf{3 7 6} \mathrm{db}$ egység & $\mathbf{1 4 5} \mathrm{db}$ egység \\
\hline
\end{tabular}

Ezzel egy időben elrendelték a III. INTERNACIONALE csatacirkáló osztály két egységének az építését. Ebből a KRONSTADT ismert (32.240/38.361 t vízkiszorítás), ez Leningrádban épült, eredetileg $3 \mathrm{db} 3$ löveges $(30,5 \mathrm{~cm})$ toronnyal, 1939. július 15-én kezdték el. A második egységet Nyikolajevben éppen hogy elkezdték (SZEVASZTOPOL), amikor a munkálatok 1941 januárjában leálltak.

A harmadik egység a SZTALINGRÁD (?) építését már el sem kezdték. 1940 nyarán a munkák leálltak, acélhiány lépett fel, így csak 10-12\%-os készültségi szintig jutottak el. Ezekre szánták a Németországtól vásárolandó $3 \times 2 \mathrm{db}$ 380 mm-es löveget a BISMARCK toronnyal együtt. A leningrádi egységet 1950-ig lebontották, a romos nyikolajevit 1945 után szétvágták.

\section{4. ábra. A KIROV Kréta partjainál, 1967 után}

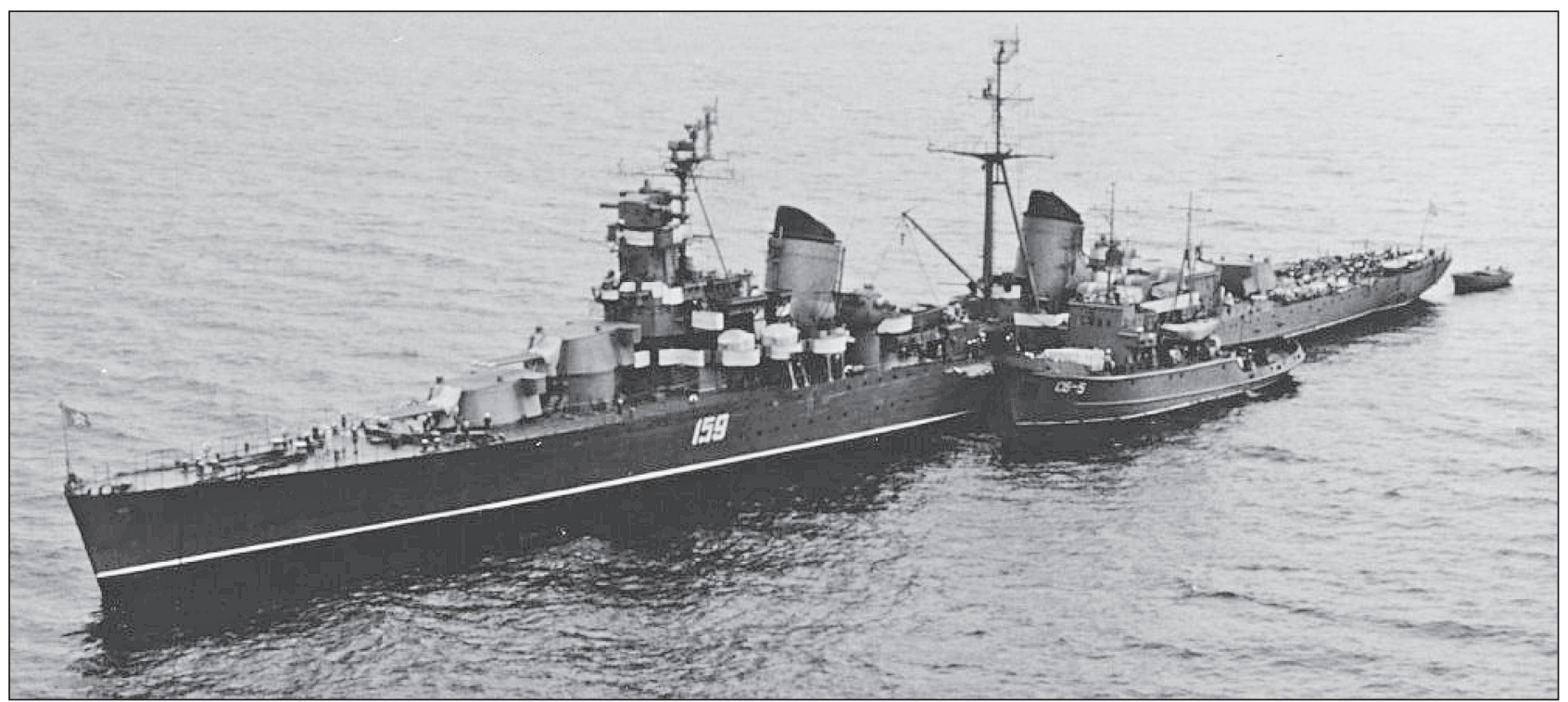




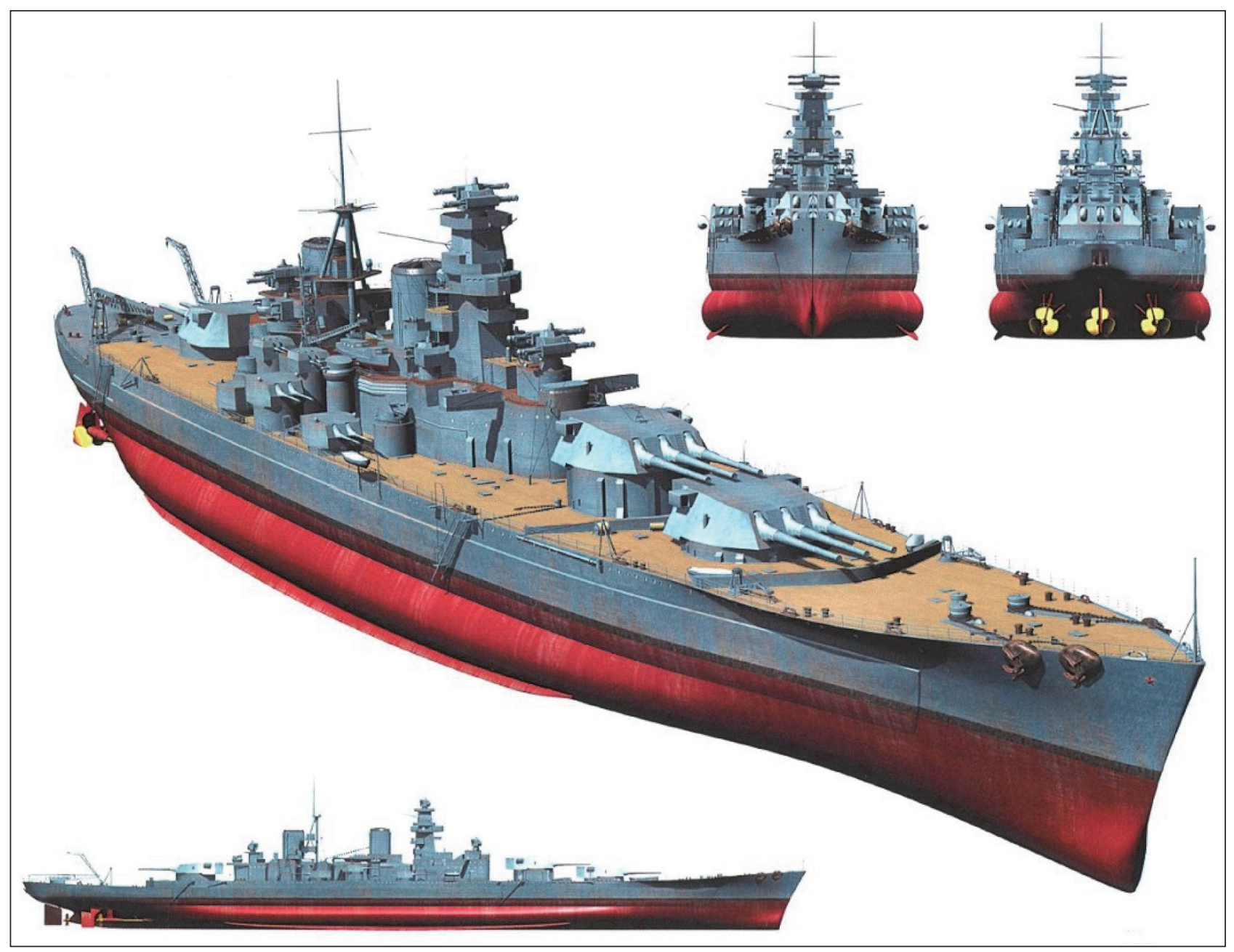

5. ábra. SZOVJETSZKIJ SZOJUZ osztályú csatahajó-terv grafikája. Az osztály mind a négy tagját 1938-1940 között kezdték építeni

\section{6. ábra. A SZOVJETSZKIJ SZOJUZ osztály nézeti rajzai}

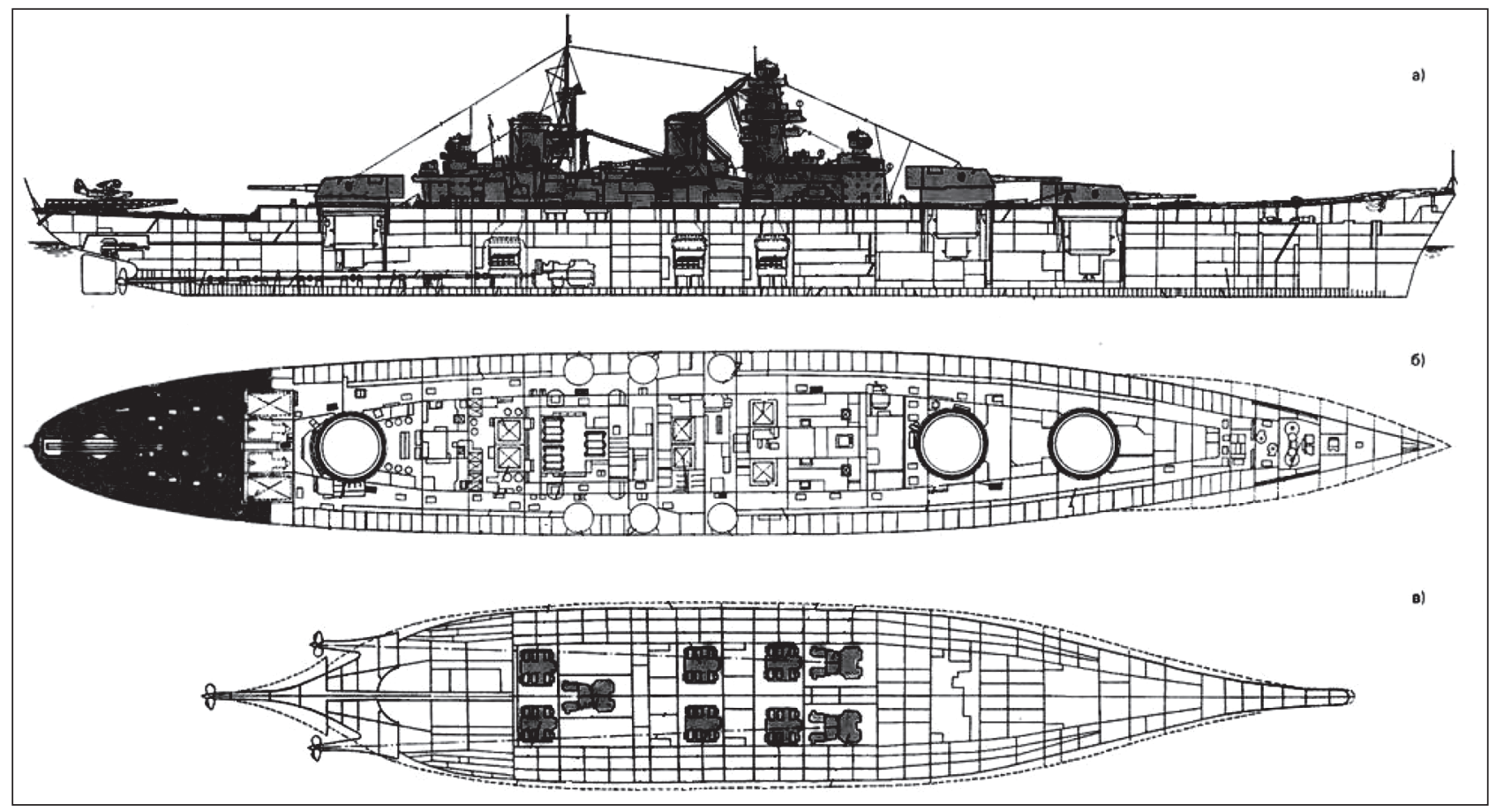

$68 \rightarrow$ HADITECHNIKA $\quad$ LI. évf. 2017/2 


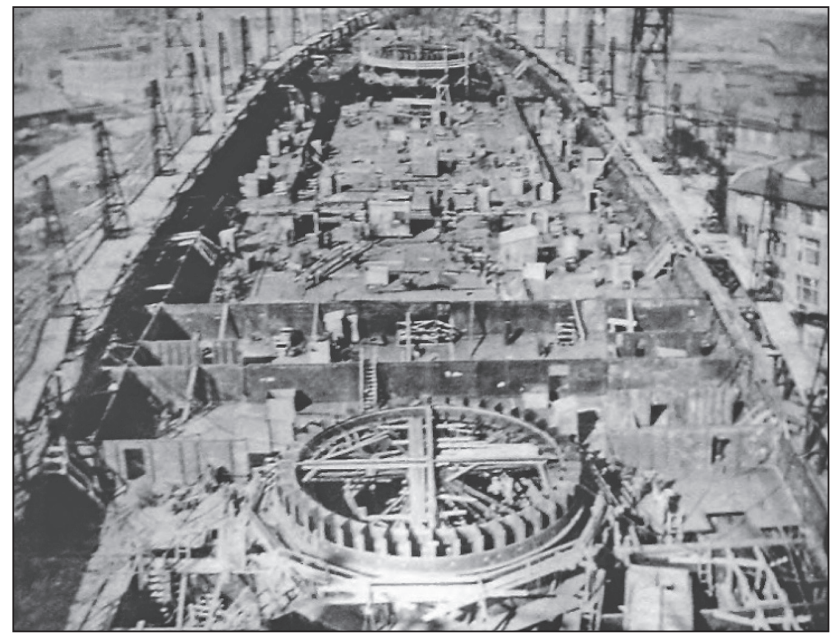

7. ábra. A SZOVJETSZKIJ SZOJUZ osztályú csatahajók elsó egysége 1941 augusztusában, a nyikolajevi hajógyárban

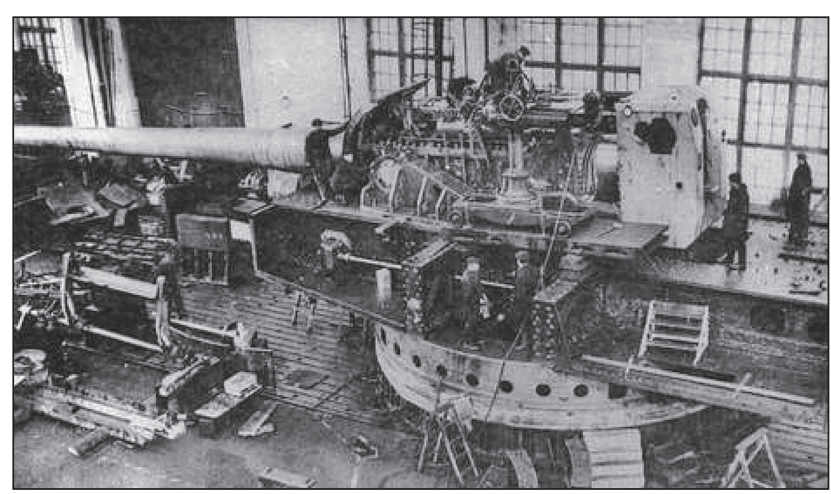

8. ábra. A SZOVJETSZKIJ SZOJUZ csatahajó tornyának építése a 40,6 cm-es löveggel

A II. világháború utáni sztálini első 5 éves terv (19461950) az újjáépítés, pótlás, zsákmányanyag-begyűjtés időszaka volt. Számszerűen a flotta jelentősen nőtt, de harcértéke - a sok idegen anyag, alkatrész, lőszerhiány, kiképzetlenség miatt - nem javult.

\section{A ZSÁKMÁNYANYAG-KÉSZLET}

Németországból: 1 intakt könnyűcirkáló (NÜRNBERG) ADMIRAL MAKAROV néven, 1 nehézcirkáló befejezetlenül (SEYDLITZ), 1 repülőgép-hordozó befejezetlenül (GRAF ZEPPELIN), $10 \mathrm{db}$ ép torpedóromboló, $10 \mathrm{db}$ tengeralattjáró, $44 \mathrm{db}$ aknaszedő és parti hajó, 30 db több típusból álló torpedóvető naszád, mintegy 30 gyorsnaszád és parti naszád, több segédhajó. Ezek jelentős része rongálva, illetve robbantva. Az elsüllyesztett szállítóhajók, utasszállítók stb. közül mintegy $20 \mathrm{db}$, de egy részük nem volt kiemelhető.

Az 1943-ban vízibombával a Finn-öbölben elsüllyesztett U250-es német VII C osztályú tengeralattjárót 1944-ben kiemelték, kijavították. Ez volt az első német modern egység, amelyet tanulmányozhattak.

Gdynia kikötőjének bejáratában, keresztben volt önelsüllyesztve a GNEISENAU csatacirkáló, amelynek oldalába hét torpedót lőttek a németek. Ezt 1946-1949 közti munkával emelték ki lengyel és szovjet búvárok és emelőosztagok bevetésével, mert használhatatlanná tette a kikötőt. A hajó fegyverzet nélküli roncs volt, de a szovjet szakemberek tanulmányozták, majd engedélyezték a lebontását. Soha nem derült ki, hasznosítottak-e valamit belőle.

A viszonylag ép állapotban elvontatott GRAF ZEPPELIN-t nem tudták megtartani, mert az 1945-ös zsákmányanyag egyezményt még alá kellett írniuk. Ez arról rendelkezett, hogy a német-olasz-japán nagy hajóegységeket egy átmeneti időszak után le kell bontani, hogy ne változtassák meg a tengerészeti erőviszonyokat. Ez a határozat Franciaország és a Szovjetunió ellen irányult, valamint tönkretette az ún. „szövetséges” Olaszország pozícióját. A Szovjetunió 1948 után már semmiféle kötelezettséget nem tartott be - de ez a tény nem tartozik e cikk témájához. 1945 után a lengyel és későbbi NDK-s vizekből kiemelt német hajókat a szovjetek lefoglalták és a megszállt országok költségére újjáépítették. Ezeket nagyrészt a kereskedelmi flottába sorolták be, ilyen munkálatok még az 1960-as években is zajlottak.

A repülőgéphordozót kivontatták a Balti-tengerre, és Észtország partjai előtt lehorgonyozva bombázógépek célhajójaként 1946 végén elsüllyesztették. Nem emelték ki a 90 m mély vízből, ma is ott nyugszik.

9. ábra. A KRONSTADT csatacirkáló osztály metszeti és nézeti grafikája

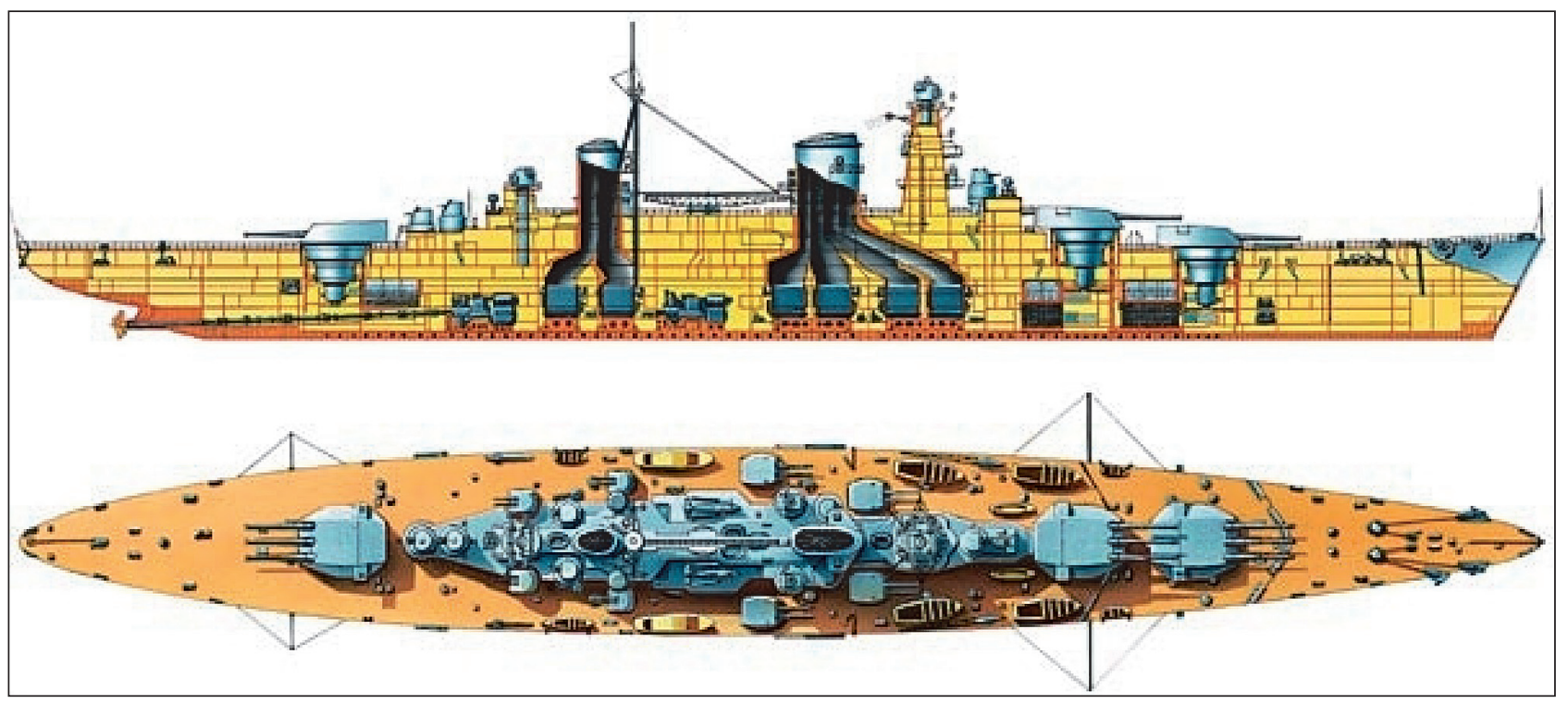




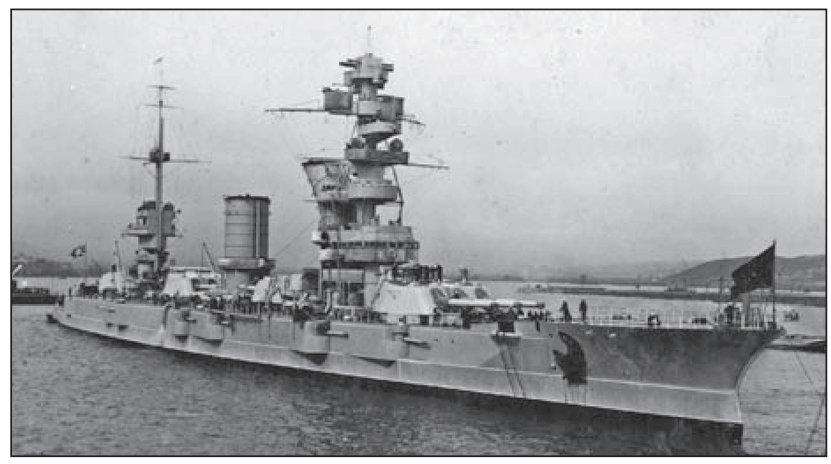

10. ábra. Az 1914-ben vízre bocsátott MARAT csatahajó, amelyet átépítettek és harcba vetettek a II. világháborúban

Olaszországból az olasz kiugrás és fegyverszünet után 1944-ben kiutaltak 1 csatahajót (CONTE DI CAVOUR), 1 cirkálót (DUCA d'AOSTA), 2 torpedórombolót, 3 torpedónaszádot, 2 tengeralattjárót és 11 db különböző gyorsnaszádot.

Ezeket a hadi helyzet miatt csak 1946-ban lehetett leszállítani, addig is Nagy-Britannia az északi-tengeri flottához kölcsönadott 1 csatahajót (ROYAL SOVEREIGN), 1 régi cirkálót, 7 torpedónaszádot és 3 tengeralattjárót. Arra ügyeltek, hogy csupa elavult, régi hajóegység kerüljön a Szovjetunióba. Ezeket 1946-ban visszaadták, jellemző, hogy Nagy-Britanniában nyomban a bontóba küldték valamennyit.

Japánból $7 \mathrm{db}$ torpedórombolót, $17 \mathrm{db}$ kísérőhajót, $2 \mathrm{db}$ kis aknarakót, 1 tengeralattjáró ellátó hajót, 1 torpedónaszádot, 3 kis aknakereső hajót, összesen 31 egységet vettek át. Ezen kívül Észak-Korea kikötőiben és partjai előtt, illetve a mandzsúriai Port Arthur és Dalien kikötőjében legalább 30, részben elsüllyesztett hajót zsákmányolt, de ezekről kimutatás sem ismert.

A japán típusok nagy részét 1949 után a Mao Ce-tung féle kínai haditengerészetnek adták át. Ott még több mint 10 évig üzemeltették azokat.

Finnországtól egy öreg partvédelmi páncélost vettek el, ez VYBORG néven üzemelt pár évig, és 4 tengeralattjáróját lebontották.

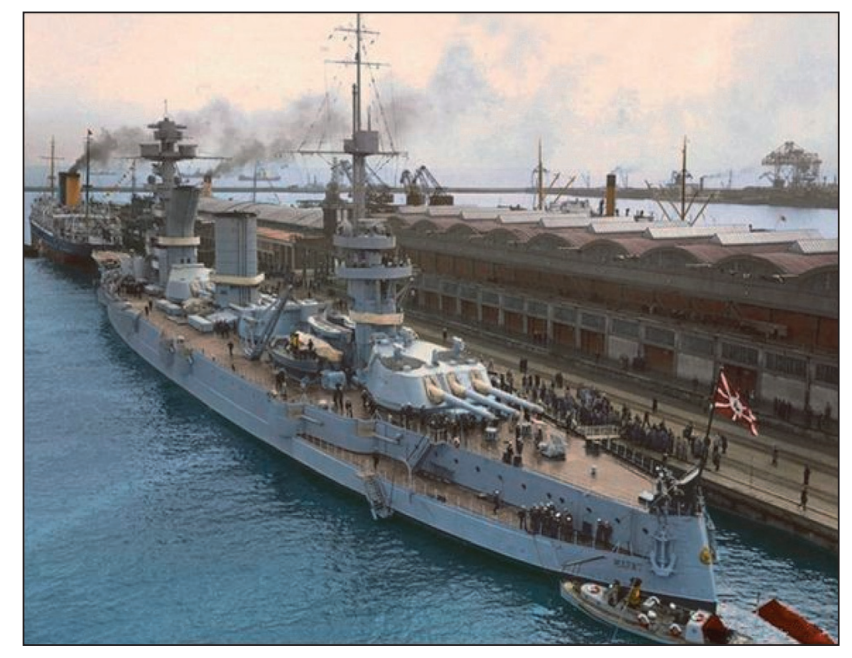

12. ábra. MARAT osztályú szovjet csatahajó 1934-ben, átépítése után. A szovjet MARAT csatahajót 1941 szeptemberében Hans Ulrich Rudel süllyesztette el, egy Ju 87-es 250 kg-os bombájával

Romániától a megmaradt 5 dunai monitort, 2 torpedórombolót, 10 gyorsnaszádot, 2 tengeralattjárót vettek át, ezeket sem használták semmire. 1955-ben, a Varsói Szerződés létrejöttekor mindegyiket visszaadták.

Az Egyesült Államoktól egy cirkáló (ex MILWAUKE), $28 \mathrm{db}$ fregatt, $34 \mathrm{db}$ aknakereső, $43 \mathrm{db}$ YMS aknakereső naszád, 250 db gyorsnaszád, 102 db SC őrnaszád, 47 db partra szállító jármű (30 db LCl, és $17 \mathrm{db}$ LCT), 59 db partra szállító naszád, $3 \mathrm{db}$ jégtörő, $25 \mathrm{db}$ mủhelyhajó és speciális egység került a szovjetekhez. Ez 592 db leszállított hajóegység.

Ezeken felül $90 \mathrm{db}$ szállítóhajó, $105 \mathrm{db}$ tengeralattjáró vadász és $197 \mathrm{db}$ TB naszád. Ezekkel együtt már $921 \mathrm{db}$ egységről van szó, a korábban említett 670 db-nál bizonyos típusokat nem számítottak be. Emellett 7784 db díze hajómotor is leszállításra került. Ezekből 1945 szeptemberéig 317 hajó elveszett, illetve sérülései miatt lebontották. Papíron 1946-1949 között visszaadtak 353 egységet, ezek közül több már a visszaúton elsüllyedt.

11. ábra. A MARAT csatahajó szerkezeti rajza. Alul a csatahajó elsüllyedésekor szerzett sérülései láthatók, amelyeket egyetlen, Ju 87-es Stuka repülögépröl ledobott 250 kg-os bomba, illetve az annak hatására felrobbant löszerraktár okozott

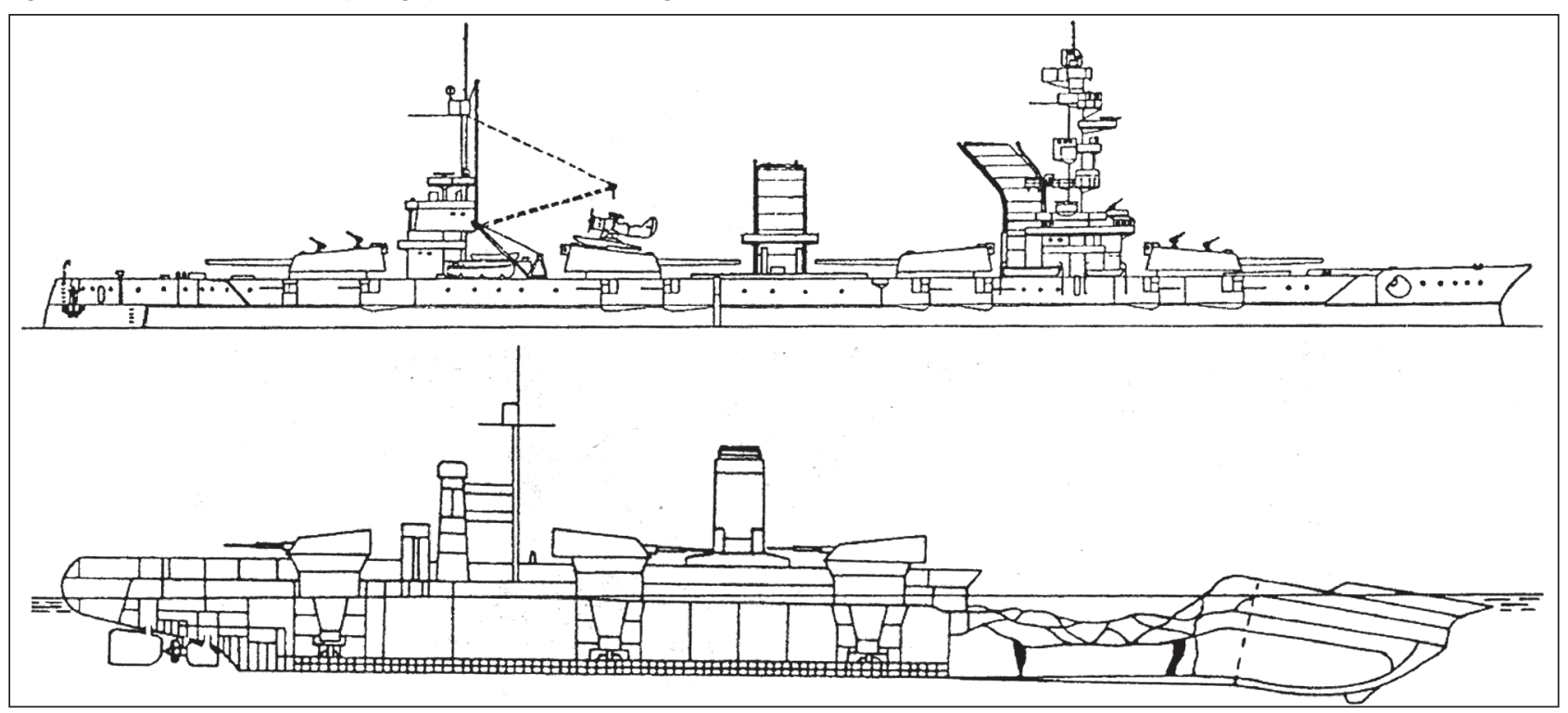




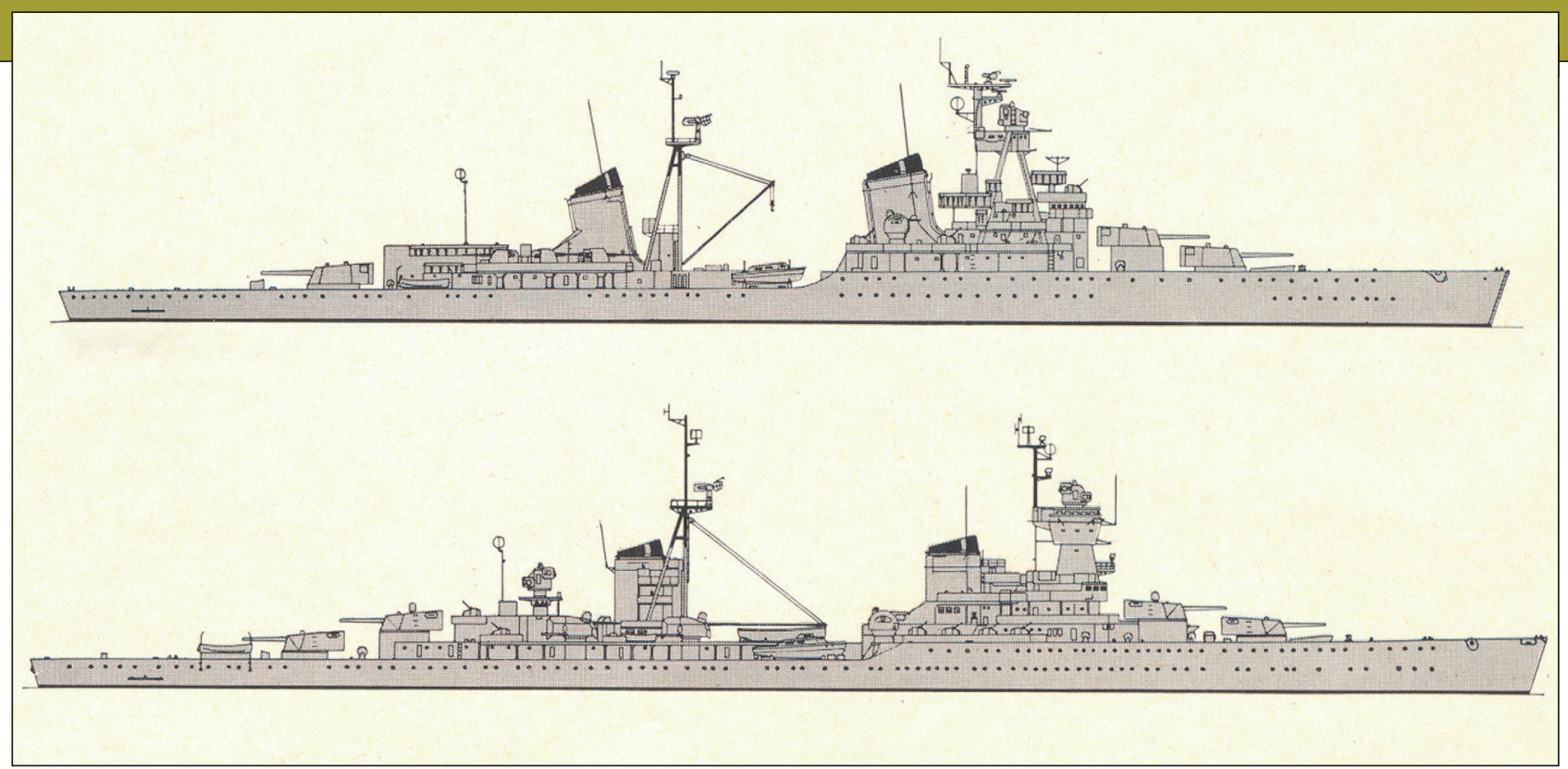

13. ábra. A KIROV és a CSAPAJEV könnyű cirkálók nézeti rajzai

Nagy-Britanniából $9 \mathrm{db}$ torpedóromboló, $4 \mathrm{db}$ tengeralattjáró (ebből 1 db szállítás közben elsüllyedt), 6 db aknakereső hajó, pár db US eredetű gyorsnaszád került át a Szovjetunióba.

Kanadából 10 db Type MMS-1001 aknakeresőt tartottak nyilván a szovjetek.

Összefoglalva, a mai napig nem derült ki, hogy miért nem próbálták befejezni az 1940-ben megvásárolt LÜTZOW nehézcirkálót (a SzU-ban TALLIN), amely 65\%ban készen volt és két toronyban 4 db 203 mm-es lövege is bent volt. Birtokukba került a testvérhajója a SEYDLITZ is, félkész állapotban. Nehézség nélkül megépíthetők lettek volna szovjet fegyverzettel. Akkor még a $3 \mathrm{db} 180 \mathrm{~mm}$-es lövegü tornyok rendelkezésre álltak a KIROV osztály anyaga miatt. Sokkal korszerübbek voltak, mint bármely később hajó a SZVERDLOV osztályból, még másolatban gyártható is lett volna. Nincs magyarázat azóta sem, 1955 után lebontották őket.

A szovjet gyárak - a nyikolajevi kivételével - befejezték az 1941-ben megszakított építésű hajókat. A Balti Flottánál 4 db KIROV osztályú cirkáló volt aktív, a Komszomolszk nad Amúr befejezett 2 db-ot a Csendes-óceáni Flottának. A CSAPAJEV cirkáló osztály mind a 4 hajóját 1946-1948 között fejezték be, 2-t a Fekete-tengeren, 2-t a Balti-tengeren. Az ötödik egység hajótestét Nyikolajevben lebontották. Készült még 6 torpedóromboló és 6 tengeralattjáró, mivel már majdnem készen álltak.

A visszafoglalt nyikolajevi gyárban lebontották az ott álló, alig 7,5\%-os készültségű 55000 t-s SZOVJETSZKIJ SZOJUZ csatahajó- és 15000 t-s cirkálótestet, meg sem kísérelték a tovább építését.

Leningrádban lebontották az alig 10-12\%-os állapotú 2 db 32240 t-s KRONSTADT osztályú csatacirkáló-testet, amelyekhez a lövegtornyokat és $3 \times 2 \mathrm{db} 38 \mathrm{~cm}$-es ágyút (BISMARCK tornyok) még 1940-ben Németországból rendelték meg, de soha nem készültek el. Nem gondolták meg, hogy olcsóbb és gyorsabb lenne pár évet várni, majd ezeket javítva befejezni, mivel a lebontásra ítélt első világháborús $3 \mathrm{db}$ csatahajó, és ezek $11 \mathrm{db} 3 \times 305 \mathrm{~mm}$-es löveggel szerelt tornya, rendelkezésre állt. Ennél nagyobb lövegeket a szovjet hadiipar akkor nem is gyártott. A 406 mm-es hajóágyú-programot, egy prototípus legyártása után, 1942-ben végleg feladták.

A háború utáni program fontos állomása volt a Projekt 30bis jelű SKORY osztályú torpedórombolók gyártása, amelyekből 1945-1953 között 70 db épült meg. Ezek tervei a háború alatt már megvoltak, de acélhiány miatt nem épült egy sem, csak 1945 után. Ez a kétkéményes típus már akkor elavult volt, amikor épült, de a szovjet ipar csak ezt tudta produkálni. 1950 után többször korszerűsítették, hogy harcértékét növeljék. Ezek a típusok kaptak először robotrepülőgépeket az ágyútornyok helyére.

Menet közben módosultak a tervek, 1954-1957 között 20 db már KOTLIN osztályként készült el, más fegyverzettel. Ezek közül 1957-1959-ben 4 db már KILDIN osztályként került átépítésre robotrepülőgépes fegyverzettel. Az 1954-1957 között épült 8 egységet KOTLIN I, II jellel 1961-1969 között rakétahordozó rombolónak építették át, ebből $1 \mathrm{db}$ a lengyel flottához került.

(Folytatjuk)

\section{ForRÁSOK}

Siegfried Breyer: Schlachtschiffe und Schlachtkrezer 1955-1970 J. F. Lehmanns Verl. München, 1970.; Weyers: Taschenbuch der Kriegsflotten 1940. J. F. Lehmanns Verl. München/Berlin, 1940. Neuanflage 1973.;

Weyers: Flottentaschenbuch 1954/55. J.F. Lehmanns Verl. München, 1955.;

Alekszandr Sirokorad: Korabli i Katera, VMF. SzSzSzR. 1939-1945. gg. Harreszt, Minszk, 2002.;

Sz. Sz. Berezsnoj: Korabli i Szuda VMF. VMF. SzSzSzR. 1928-1945. Voennoe Izdatelsztvo, Moszkva, 1988.; Zicherman István: Tengerről az égbe. Anno Kiadó, Debrecen. é.n.;

G. A. Ammon - Sz. Sz. Berezsnoj: Geroicseszkie Korabli Rosszijszkogo i Szovetszkogo Voenno-Morszkogo Flotta, Voennizdat, Moszkva, 1981.;

David Fairhalt: Russia Looks to the Sea. Ebenezer Baylis\&Son Ltd., 1971, Worcester.

\section{JeGYZETEK}

1 Az II-10M, Pe-2, Tu-2, A-20, B-25 és Pe-8 típusú gépekről végzett több száz bomba ledobása különböző magasságokból és szög alatt olyan gyatra eredményt hozott, hogy Sztálin nyomban elcsapta a légierők érintett parancsnokait. Az eredményt Oroszországban először 1994-ben publikálták. 